A N N A L E S

UNIVER I TATIS M A R A E C URIE-SKŁODOW S A

LUBLIN - POLONIA

VOL. LXXVI

SECTIO B

2021

BOGDAN BUYAK

https://orcid.org/0000-0003-1496-7573

Ternopil V. Hnatiuk National Pedagogical University

Faculty of History

2 M. Kryvonosa St., Ternopil, 46027, Ukraine

buyak.bogdan@tnpu.edu.ua
ANDRII KUZYSHYN

https://orcid.org/0000-0003-3879-7337

Ternopil V. Hnatiuk National Pedagogical University Faculty of Geography

2 M. Kryvonosa St., Ternopil, 46027, Ukraine

kuzyshyn_a@tnpu.edu.ua

\title{
Change of the Electoral Sympathies of the Voters in the Western Ukrainian Region According to the Parliamentary Elections Results in 2019
}

\begin{abstract}
Zmiana sympatii wyborczych w regionie zachodniej Ukrainy według wyników głosowania podczas wyborów parlamentarnych w 2019 roku
\end{abstract}

\begin{abstract}
Abstrakt: Celem opracowania jest porównanie wyników sympatii wyborczych ukraińskich wyborców z trendami panującymi w tej kwestii w Europie. Przeanalizowano regiony Ukrainy Zachodniej (łącznie 9 jednostek) w odniesieniu do okręgów wyborczych, aby zidentyfikować związek między wynikami głosowania a szerokim wachlarzem zmiennych określających regionalny kontekst społeczno-gospodarczy, historyczny i społeczno-kulturowy. Podstawą analizy są dane Centralnej Komisji Wyborczej Ukrainy, które obejmowały dane o różnym zasięgu terytorialnym (lokal wyborczy - okręg wyborczy - obwód administracyjny). Wieloaspektowe badanie opierało się na analizie następujących zmiennych: poparcie dla partii „Sługa Narodu”, poparcie dla innych partii parlamentarnych w wyborach w 2019 r., podział głosów między partiami centroprawicowymi i liberalno-centrowymi, poparcie/opozycja „starych” i „nowych” partii parlamentarnych podczas głosowania w 2019 r. oraz analiza frekwencji wyborców. W pracy zastosowano metodę analiz przestrzennych, generalizacji i prognozowania. Wyniki przeprowadzonego badania potwierdziły niską frekwencję wyborczą (co nie jest typowe dla badanego regionu), znaczne wahania w poparciu dla bezprecedensowego lidera wyborczego (partii „Sługa Narodu”), skupienie się na młodych partiach parlamentarnych jako nadziei na zmianę. Region charakteryzował się znacznie wyższym poparciem dla partii centroprawicowych, co jest powszechnym zjawiskiem na tym terenie, oraz ogólnie mniejszym poparciem dla nietypowych poglądów liberalnych.
\end{abstract}

Słowa kluczowe: Ukraina Zachodnia; wybory; wyniki wyborów; frekwencja wyborcza; poparcie terytorialne partii; partie parlamentarne 


\begin{abstract}
The aim of the study is to compare the results of electoral sympathies of Ukrainian voters with the prevailing trends on this issue in Europe. We analyzed Western Ukraine regions (9 units in total) in relation to constituencies to identify the relationship between voting results and a wide range of variables that define the regional socio-economic, historical and socio-cultural context. The conducted research is based on the data of the Central Election Commission of Ukraine, including the data of different territorial levels of coverage (polling station - constituency - administrative region). The spatial multi-vector study was based on the analysis of the following variables: support for the "Servant of the People" party, support for other parliamentary parties in the 2019 elections, distribution of votes between centre-right and liberal-centre parliamentary parties, support/opposition of the so-called "old" and "new" parliamentary parties during the 2019 voting, as well as a spatial analysis of voter turnout. In addition, methods of spatial analysis and differentiation, generalization and forecasting were used. The results of the study showed an unconventionally low voter turnout, which is not typical for the studied region, significant fluctuations in support of the unprecedented election leader (the "Servant of the People" party), orientation to young parliamentary parties as a hope for change of the inner state of the country. The region was marked by significantly higher support for centre-right parties, which is a traditional phenomenon for this territory, and generally lower support for non-standard liberal views.
\end{abstract}

Keywords: Western Ukrainian region; elections; election results; voter turnout; territorial support of parties; parliamentary parties

\title{
INTRODUCTION
}

On July 21, 2019, the parliamentary elections were held in Ukraine, as a result of which 5 political parties became members of the parliament. Unconditional leadership was given to the liberal-centric party "Servant of the People", which was a completely new political project. Also ideologically close were the views of the party "Voice", which was also a new player on the state's political Olympus. The centre-right forces are represented by the "European Solidarity" party, which has undergone some rebranding (in the recent past, it was Petro Poroshenko's "Solidarity" bloc, which formed the basis of the party with the same name). According to ideological views (but not according to the personal relations of the leaders), the "Fatherland" party is close to the EU, which has also overcome the necessary barrier to entry. The liberal party "Opposition Platform - For Life!", formed by the representatives of powerful oligarchic structures of the state, joined the parliament, too. Generally, 5 out of 22 political parties have entered the Parliament of Ukraine (Verkhovna Rada). The "Servant of the People" became the first party in Ukraine after the communist era, which gained an absolute majority of seats in the parliament, allowing the government to appoint its own nominees and form a mono-majority in the parliament.

Changes in the Ukrainian political scene coincided with rising populist spirits and parties in Europe as well as declining support for parties with 
established and experienced leaders such as Alternative for Germany (Alternative für Deutschland), the Freedom Party of Austria (Freiheitliche Partei Österreichs), the Sweden Democrats (Sverigedemokraterna) or the Danish People's Party (Dansk Folkeparti). They were the forerunners of the centrifugal campaigns promotion in Great Britain and the United States, which paved the way for the Brexit vote and Donald Trump's victory, as well as the best result ever of the French National Front in 2017. The question is to what extent the results of the Ukrainian elections in 2019 correspond to this broad international context.

The specific issue that we intend to address in detail in this article is related to the spatial distribution of such tendencies. We conducted a survey of the constituencies of the Western Ukrainian region (9 units in total) at the level of administrative regions by constituencies to identify the relationship between voting results and a wide range of variables that determine the regional socio-economic, historical and socio-cultural context. This approach can be interesting for at least three reasons.

Regional research of this type is the key to a proper understanding of the relationship between constituency formation and election results. The conclusions may be relevant for other regions of Ukraine, and possibly even for other states.

We should agree with Lasoń and Torój (2019) that over the recent years, there has been a growing interest in the role of party leaders in elections and personalization of politics. Today, there is enough research, in particular by Polish scholars, aimed at refuting the hypothesis that the party leader is the main and determining factor in electoral decisions in the case of new parties, rather than in the case of more institutionalized and already established party structures. According to the current trend of research, spatial research allows us to record the subtle effect of local leaders' charisma on the outcomes of voting. At least, this is the case when elections are held in constituencies, and probably become the only non-declarative method of studying this phenomenon (Lasoń, Torój 2019).

In our scientific research, we conducted a spatial multi-vector study, which was formed under the influence of the following variables: (1) unprecedented support for the "Servant of the People" party, (2) support for other parliamentary parties in 2019, (3) split between centre-right and liberal-centrist parties at the parliamentary level, (4) support/opposition of the so-called "old" and "new" parties, and (5) voter turnout.

The data used in the work are available on the website of the Central Election Commission of Ukraine (https://cvk.gov.ua), including the data from different territorial levels of coverage (polling station - constituency - administrative region). A source of the data was also Ilko Kucheriv Democratic Initiatives 
Foundation (2019). At the final stage, we applied spatial econometric models to take into account the presence of additional spatial processes.

\section{MATERIAL AND RESEARCH METHODS}

According to the Central Election Commission of Ukraine, the "Servant of the People" party was supported by $43.16 \%$ of those who took part in the elections, which gave 254 out of 424 seats (BBC News...). The "Opposition Platform - For Life!" party received $13.05 \%$ of the votes (43 seats). It is worth mentioning that in this format, both parties participated in the elections for the first time. Within the Western Ukrainian region, these political forces had mixed support. If the "Servant of the People" had about the same number of supporters in the districts of this region as in Ukraine in general, the "Opposition Platform - For Life!" had minimal support, which would not ensure the seats for this political structure in the parliament. Assessing the spatial distribution of the election results, it should be noted that the "Servant of the People" party was more popular among voters in the eastern and south-eastern constituencies of the Western Ukrainian region. At the same time, the support of the parties "European Solidarity", "Fatherland", "Voice" was greater in the western and central constituencies of this region. This may indicate that the electorate of these three parties had a similar profile, as well as that the "Voice" party, being a newcomer to the parliamentary election race, intercepted some of the "European Solidarity" voters.

In recent years, research on the determinants of electoral behaviour, that is measured by voter turnout, has expanded significantly. A thorough analysis of such scientific research was conducted by Lasoń and Torój (2019), who noted that only in 2014, about 200 studies were published. Their research showed that the voter turnout survey, conducted as a multivariate regression analysis, includes at least one of 14 variables:

- socio-economic: population, population concentration (although this is weakly related to voter turnout), population stability (measured by three factors: population mobility, population growth and percentage of house owners in the community), income homogeneity and ethnic homogeneity, share of minorities (voter turnout is lower if minority share in population is higher), past turnout,

- political: proximity of elections (Fauvelle-Aymar, François 2006) - there is a positive relationship between the competitiveness of elections and the percentage of voters who come to the polls, political fragmentation (Dettrey, Schwindt-Bayer 2009), election costs (Haydukiewicz 2011; Hogan 2013; Holbrook, Weinschenk 2014), 
- institutional: electoral system (Eggers 2015; Endersby, Krieckhaus 2008), compulsory voting (Fowler 2013), registration requirements (Ansolabehere, Konisky 2006) and simultaneous elections (Mansley, Demsar 2015; Nikolenyi 2010). Such studies were also conducted by Kuzyshyn (2017, 2019, 2020) and a number of other scientists-geographers of Ukraine (Bakumov 2015; Brajchevskyj 2013; Cherkashyn 2005; Kolodij 2006; Vyshnyak 2008), assessing the features of electoral culture and changes in the electoral field within the territory of Western Ukraine.

When looking for spatial determinants of voting behaviour, some other aspects of the country should be considered, both in the long run and related to the specific electoral circumstances in 2019. After the first elections in Ukraine and the systemic post-communist transformation, which began in 1991, significant regional differences could be observed both in the elections and in the turnout. Today, two main aspects of the spatial differentiation of electoral behaviour can be found in the scientific literature on electoral geography. According to the first, the main reason for electoral disproportion is historical and cultural circumstances, while the second one is focused on socio-economic factors (Zarycki 1997, 2002). The first theory emphasizes the relevance of Ukraine's entry into various state formations (domination of the Russian and Austro-Hungarian empires in these territories, later the Soviet Union and the subordination of certain territories, in particular Western Ukraine, to Poland, Romania, Czechoslovakia). It affected the sentiments of the local population, which periodically made attempts to declare the independence of certain regions of Ukraine or its integral unification within one state. This became the basis of the historical formation of political views. First of all, it affected those regions of Ukraine that nowadays have access to the border. This pattern is often explained by the long tradition of parliamentarism that was characteristic of the society, which was formed in the Polish and Austrian states, while the eastern communities developing within the Russian Empire, due to the authoritarian regime, did not have the appropriate conditions for progress. Here we can draw some parallels with the formation of electoral commitment in different parts of Poland (Kowalski 2003, 2004). Living in such an environment has led to the formation of clear social norms and political views (Krzemiński 2009). The second concept rejects historical influence, explaining electoral behaviour mainly by modern socio-economic situations. This approach is also reflected in the study of Lasoń and Torój (2019).

As for the election campaign itself, the "Servant of the People" party has made a number of attractive promises, the most important of which was to fight corruption and form a completely new political face of the country by totally renewing its management at all levels. These key proposals clearly shaped the 
renewed preferences of the electorate, which were not traditional for most constituencies and administrative territories of Ukraine in general and for the Western Ukrainian region in particular.

The parliamentary elections in July 2019 were a kind of continuation of the presidential elections held in March 2019, when the candidate of the same political unit won unequivocally. The promise of a complete reform of the government and changes in the positioning of relations with the population became a condition for the weakening of other parties in Ukraine and serious support for the new political project.

The main goal of the "European Solidarity" campaign was to retain its voters after a long period (since 2014) of functioning as the ruling party role, which covered various phases of the financial and economic crisis, although there were a number of achievements on the European integration vector and openness to Europe. The party faced an additional, unexpected threat of losing voters due to the creation of new liberal ("Servant of the People") and pro-European ("Voice") parties. Both of them have largely focused their program on young voters with higher education and entrepreneurs interested in the liberal economic policies they have long been hoping for. Their promise was to simplify the tax system, to eliminate trade union and pension benefits, and to improve the education system according to the labour market. It also contributed to the ideological neutrality of the state. The political proposal was aimed mainly at the broad strata of the indigent people, who dominate the country.

At the same time, our study is of a sub-regional nature and focuses on a large region of Ukraine. When studying it, we should focus on institutional and political variables, and not just on socio-economic ones. Common institutional determinants that can be applied to all regions include: voting is voluntary, pre-registration is not required, voters can change the place of pre-registration if necessary whenever they cannot be at the place of residence on the election day. Constituencies are formed by merging administrative territories and are formed on a territorial basis, taking into account the recommended number of voters (on average - 160,000 people).

In Europe, the geographical variability of the determining factors of voter turnout was studied by Mansley and Demsar (2015). The example of the London mayor election in 2012 showed that voter behaviour changes geographically and that some variables that are thought to affect turnout in some way act unevenly in space and sometimes even change direction to the opposite of the traditional expected effect. Attention to electoral activity is also given in the studies of the European Parliament (Abstention and Voting...). As for France, Saib tried to determine the share of uneven voter turnout, which is directly the result of 
specific socio-economic factors of the studied areas, in order to distinguish the specific effect of the neighbourhood (Saib 2017).

\section{RESEARCH RESULTS AND DISCUSSION}

The data from the Central Election Commission of Ukraine was used in order to conduct a spatial econometric survey of voter turnout, support for individual parties, especially the unprecedented support of the "Servant of the People" party, the distribution of votes between centre-right and liberal-centre, as well as old and new parties.

While trying to explain the results of the voting and the victory of the "Servant of the People" party, we must take into account the sharp criticism of the previous parliament and the parties represented in it, as well as a number of attractive (but potentially very expensive) promises to voters. Due to the fact that the "Servant of the People" party accused the previous government of the policy of supporting big business and creating preferences for it, we can assume that the economic situation in the regions (meaning the dynamics of VAT revenues, per capita income/1,000 people) may have affected the voting results in such a way that the population did not feel the expected increase in their own well-being. Therefore, they preferred to vote for the "Servant of the People" party.

The introduction of health care reform, which was not systemic in nature and caused serious disapproval among the population, was also a condition of non-support of the ruling parties like "European Solidarity" and "Fatherland". Therefore, a number of demographic variables can be used for our analysis, such as the number of children under the age of 14, the working age population, and unemployment rates. It seems fair to say that there is a link between the demographic structure and the support of specific parties. Thus, young people supported the newly formed party associations in these elections ("Voice", "Servant of the People"), with the growing age of voters increased support for centre-right parties ("European Solidarity" and "Fatherland").

Taking into account the variables related to the structure of the economy, the share of agriculture (meaning the percentage of employed in the agricultural sector) was supposed to increase support for the "Servant to the People" party through their campaign promise to introduce a law that would allow land to be purchased exclusively by Ukrainian farmers.

On the other hand, it is expected that the variables related to economic activity, such as employment per 1,000 of population and the level of the population welfare, are expected to have a positive effect on the support of liberal parties ("Servant of the People" and "Opposition Platform - For Life!"), especially for 
"Servant of the People", which mainly focused its program on young voters with higher education and entrepreneurs interested in liberal economic policy.

The data set contains various cultural and historical factors that shape the commitment to centre-right parties that are more dedicated to national-patriotic ideas. One of the components of this process is voter turnout. Assessing it, it should be emphasized that the population of the areas of this region is marked by an active public position. However, there is a steady trend in the decreasing number of those who expressed their opinion during the voting. Thus, in the elections to the Verkhovna Rada in 2006, $70 \%$ of the electorate of the research region participated, in the 2007 elections $-67.1 \%$, in the 2012 elections $-66.1 \%$, in the 2014 elections $-59.1 \%$, and in $2019-49.3 \%$. At the same time, these indicators are significantly higher than the Ukrainian average (except for 2019 $-49.8 \%$ - because the elections took place during the holiday season and a significant part of voters could not physically participate in the elections due to the fact that they were outside the permanent place of registration) (Fig. 1).

Different regions have their own stable trends. Traditionally, low turnout is typical for polyethnic regions like Zakarpattia and Chernivtsi (these are regions where the share of ethnic Ukrainians is 80 and $75 \%$, respectively, and the

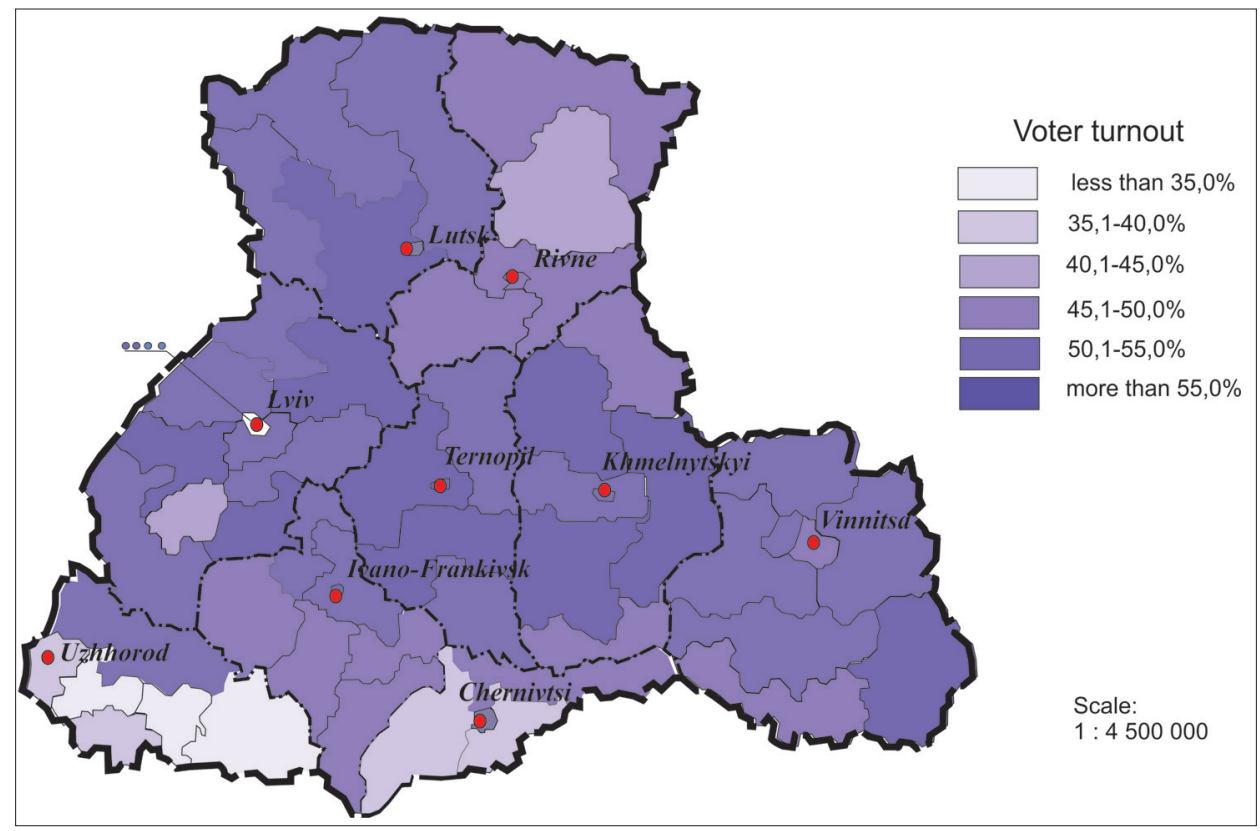

Fig. 1. Voter turnout during the 2019 Verkhovna Rada elections within the Western Ukrainian region (in terms of constituencies) (created on the basis of the Central Electoral Commission of Ukraine official website) 
influences of the Hungarian and Romanian populations are significant), where the turnout is $7-15 \%$ lower than in the region in general for the current election year. High turnout rates are typical for the regions of Galicia (Ivano-Frankivsk, Lviv and Ternopil) where during all the election years the turnout was $1-11 \%$ higher than in the region in general. At the same time, certain intra-regional territories were marked by specificity, where the indicators of participation in the electoral process differ significantly from those that were typical for the region in general or for a certain regional administrative unit.

In the Zakarpattia region, during the electoral overview of 2006 and 2007, the lowest (54-56\%) turnout was in Rakhiv, Tiachiv and Khust districts, which are characterized by the dominance of the dispersed (scattered) type of rural settlements, which do not always coincide with the threshold of territorial accessibility of polling stations. During the redistribution of constituencies (gerrymandering technologies) in 2012 and 2014, it became clear that the most passive electorate is characteristic of Rakhiv and Tiachiv districts (33-37\% of turnout at polling stations).

The highest turnout rates are in administrative districts within Lviv and Ivano-Frankivsk regions, which border each other (Zhydachiv, Rohatyn and Halych).

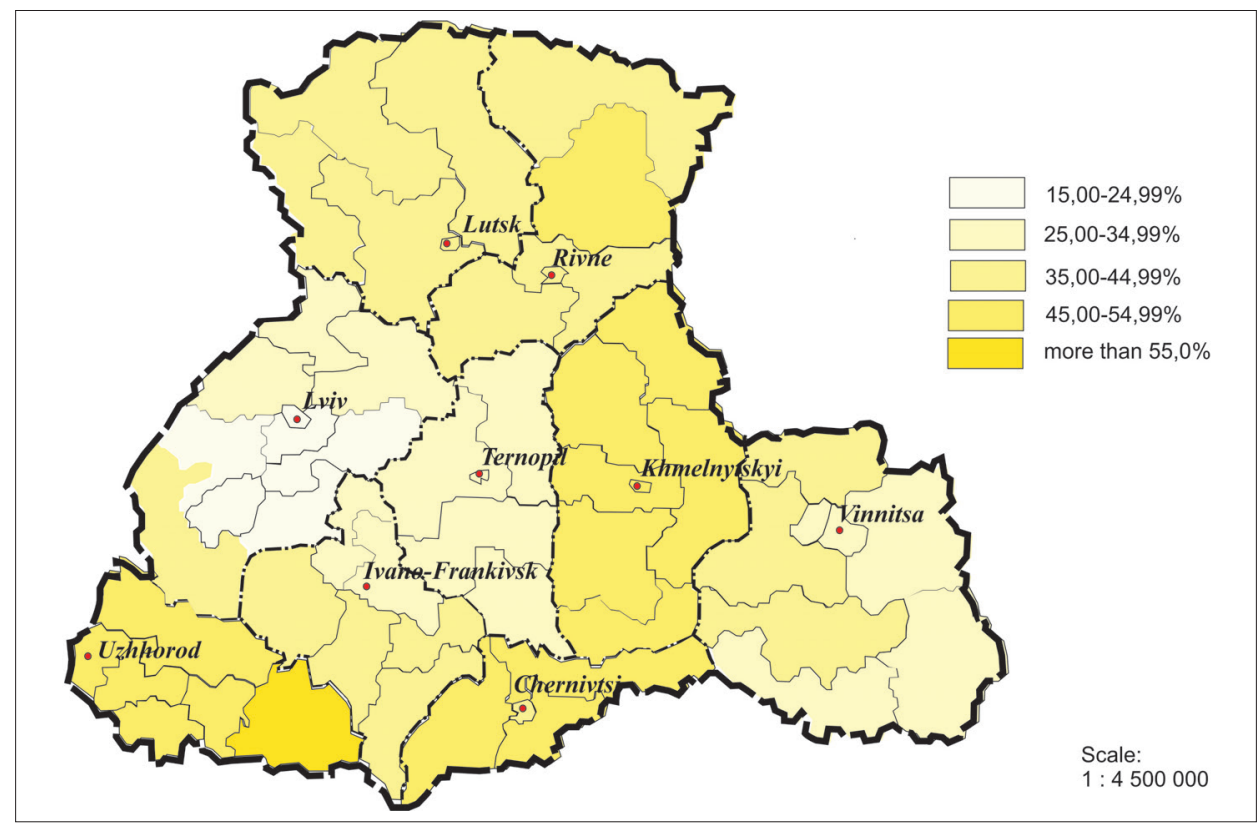

Fig. 2. Support of the "Servant of the People" party during the 2019 parliamentary elections within the Western Ukrainian region (in terms of constituencies) (created on the basis of the Central Electoral Commission of Ukraine official website) 
This suggests a significant level of electoral discipline within these territories. During the 2006 and 2007 elections, the turnout ranged here from 85 to $79 \%$ of the total number of voters. Even as a result of the new redistribution of constituencies, the same administrative districts retained the leading positions in terms of turnout (65-74\%). In 2019, these regions remained the all-Ukrainian leaders in terms of the number of those who took part in the elections (Ivano-Frankivsk region $-54.2 \%$, Lviv region $-53.4 \%$ ). These indicators demonstrate clear trends specific to certain territories of the Western Ukrainian region and confirm that these territories are marked by traditions of participation or absenteeism regarding the electoral process as such.

In general, the 2019 election campaign will go down in history of electoral geography of Ukraine as the campaign with the greatest support of one political party, i.e. "Servant of the People" (Fig. 2). We mentioned the ideological approaches to its formation above, but now we will focus on the spatial support analysis for this political force. Generally, in Ukraine, $43.16 \%$ of people voted for this party in the elections. This indicator fluctuated significantly within the areas of the Western Ukrainian region (average indicator - 39.76\%). In the easternmost area of the region that is Vinnytsia, the average support for this party was $38.23 \%$. Conventionally, the party had the lowest support in the regional centre (less than $31 \%$; this is reasonable, due to the popularity of two political forces, for which this city is a kind of "small homeland" because of the origin of their leaders - "European Solidarity" and the political party Groysman's Ukrainian Strategy), whereas the highest support was in the southern administrative districts of the region (Kryzhopil, Mohyliv-Podilskyi, Pishchanka, Chechelnyk, Yampil districts) - more than $46.5 \%$. In Khmelnytskyi region, this party structure had extremely uniform support in all administrative territories - in the range of $45-49 \%$. Ternopil region has unconventionally strongly supported the "Servant of the People" party, which represents a liberal ideology. On average, it was supported by one third of the region's electorate and this support was also extremely uniform - 29-33\%. Ivano-Frankivsk region is characterized by a significant amplitude of differences in indicators. The lowest indicator (25.61\%) was in Ivano-Frankivsk, and the maximum support was noticeable in the southern districts of the region (Verkhovyna, Kosiv, Sniatyn). Lviv region was the only one in the region, and in Ukraine in general, within which the party "Servant of the People" did not take the first place according to the voting results. There was also unequal support for this party in the region. The lowest support was in Lviv and administrative districts around Lviv (15.5-17\%), and the highest one was in the foothill (south-western) districts of the region (about 29\%). Zakarpattia and Chernivtsi regions were the only ones in the research region in which 
more than half of the electorate voted for the leader of the parliamentary race (in Uzhhorod and Chernivtsi alone, about 43 and 44\% of voters voted for this party, respectively). The regions of Volyn subregion (Volyn and Rivne regions) are also characterized by small fluctuations in the support of this party: the minimum $38 \%$ was typical for the city of Rivne, the maximum $45.5 \%$ for the northern districts of Rivne region (Berezne, Kostopil, Sarny).

One can try to justify the popularity of this political force at this stage by a kind of globalization influences, i.e. mass capture and replication of western views and behavior - lifestyle, liberal democracy, market economy, primacy of individual rights and freedoms over collective ones. At the same time, there are growing protests in society regarding the psychological fatigue of waiting for change. At the same time, regional differences in support can be justified by unstable political preferences that are characteristic of polyethnic regions (Zakarpattia and Chernivtsi regions), as well as traditions of support of other ideologies that are characteristic of Galician regions (Lviv, Ternopil, Ivano-Frankivsk). East Podillia and Volyn regions occupy a somewhat intermediate position as far as this issue is concerned.

It is worth mentioning the distribution of votes between the new parliamentary parties that received their seats in the Ukrainian parliament ("Servant of the People" and "Voice") and parties that have already been in parliament in previous terms ("European Solidarity", "Fatherland", "Opposition Platform - For Life!"). In 2019, the electorate preferred new political forces, which, however, represented different ideologies. Such confrontation is a sign of the struggle for ideological leadership, which results in leadership in spheres of influence (Tab. 1).

On average, within the Western Ukrainian region, these parties were supported by almost $49 \%$ of voters. The lowest support was common for Ternopil (this can be explained by the conservative views of the local population) and Vinnytsia (within this territory there was significant support for the young political force Groysman's Ukrainian Strategy, which did not manage to join the parliament but its leader has significant influence in this area). The maximum commitment of the electorate to the new political forces was within the Zakarpattia and Chernivtsi regions (in each of them, these political forces were supported by $55 \%$ of voters). This is justified by the dominance of cosmopolitan views among the local population, its polyethnicity and the significant influence of populist ideas inspired by European trends. This is clearly seen in the constituencies along the borders with Hungary and Romania.

Among the experienced parliamentary parties in the region, "Fatherland" and "European Solidarity" received the most support. The party "Opposition Platform - For Life!", due to its ideology and representatives, did not have support in the region, so it is not a significant factor in assessing electoral preferences. 
Tab. 1. Indicators of support for new and mature parliamentary parties in the Western Ukrainian region during the 2019 parliamentary elections (\%) (created on the basis of the Central Electoral Commission of Ukraine official website)

\begin{tabular}{|c|l|c|c|c|}
\hline \multirow{2}{*}{ Region } & \multicolumn{2}{c|}{ Political party } & \multirow{2}{*}{$\begin{array}{c}\text { General support of } \\
\text { parliamentary parties }\end{array}$} \\
\cline { 2 - 4 } & $\begin{array}{c}\text { New parliamentary } \\
\text { parties }\end{array}$ & $\begin{array}{c}\text { Mature parlia- } \\
\text { mentary parties }\end{array}$ & 65.19 \\
\hline 2 & Vinnitsa & 41.58 & 23.61 & 73.68 \\
\hline 3 & Zolyn & 48.78 & 24.90 & 77.08 \\
\hline 4 & Ivano-Frankivsk & 54.75 & 22.33 & 75.08 \\
\hline 5 & Lviv & 47.30 & 27.78 & 76.10 \\
\hline 6 & Rivne & 45.11 & 30.99 & 74.28 \\
\hline 7 & Ternopil & 49.88 & 24.40 & 70.93 \\
\hline 8 & Khmelnytskyi & 44.69 & 26.24 & 73.86 \\
\hline 9 & Chernivtsi & 50.91 & 22.95 & 81.14 \\
\hline & On average in the Western & 55.22 & 25.92 & 74.15 \\
\hline & Ukrainian region & & & 78.27 \\
\hline
\end{tabular}

The average support rate for these parties in the region is a quarter of voters, which is quite low for the Western Ukrainian region. Lviv region alone demonstrated almost $31 \%$, which is natural due to the significant traditional support of experienced centre-right parties, and about $23 \%$ in Zakarpattia and Khmelnytskyi regions.

An interesting criterion for assessing the political maturity of the region's electorate can be considered the indicators of support for political parties that have entered the parliament. Thus, it is possible to state about the rational thinking of voters in a particular region, as well as the convincing support of these parties, which had the support of more than $5 \%$ of voters. However, the second criterion is not always ostentatious, as parliamentary parties have not overcome the election threshold in Ukraine.

According to the CEC, on average, more than $74 \%$ of voters in the Western Ukrainian region supported those parties that entered the parliament (this figure is quite different from the national one). The lowest support for parliamentary parties was in the easternmost areas of the research region, namely Vinnytsia region $-65.19 \%$. The maximum support for parliamentary parties was in Chernivtsi region (over 81\%). In general, in 5 areas of the region (Zakarpattia, Ivano-Frankivsk, Lviv, Rivne, Chernivtsi), the support for the parties that entered the parliament exceeded the regional average. At the same time, only one region 
of this territory exceeded the national indicator of support for parliamentary parties, namely Chernivtsi region (Tab. 2).

Tab. 2. Indicators of support for parliamentary parties in the Western Ukrainian region according to the results of the 2019 parliamentary elections (\%) (created on the basis of the Central Electoral Commission of Ukraine official website)

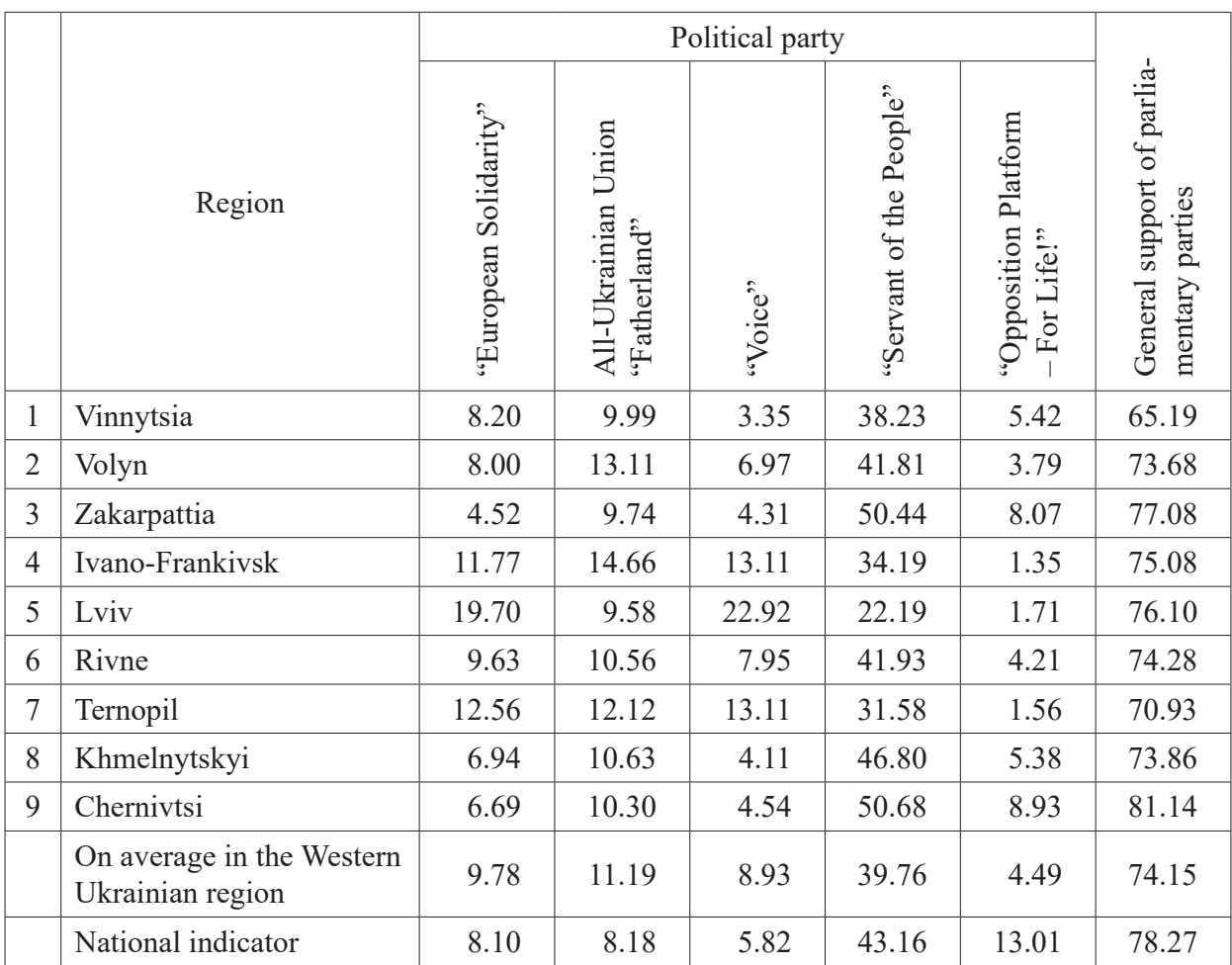

In terms of individual parties that entered the regional parliament of the Western Ukrainian region, they also showed mixed support, and, at the same time, significant deviations from the national indicator. The parties "European Solidarity", the All-Ukrainian Union "Fatherland", "Voice" were marked by higher support than in the country generally. In Lviv region, "European Solidarity" and "Voice" had significantly higher support than in the whole country generally. This can be justified by several regional reasons. First of all, Lviv region is the "small homeland" of the leader of "Voice" and this became a prerequisite for such support. "European Solidarity" was supported due to the worldview of the regional population, which in all election campaigns of independent Ukraine showed support for pro-European parties. The same reason justifies the substantial support for the All-Ukrainian Union "Fatherland" and "European Solidarity" in most areas of the Western Ukrainian region. 
The "Servant of the People" party had slightly lower support in the Western Ukrainian region than in Ukraine in general. The fact of the predominance of parties with such views should now be considered a voting phenomenon for these areas. In five regions of this territory, the indicators of support for the leader of the parliamentary elections were higher than the average one in the region. The five regions include Volyn, Zakarpattia, Rivne, Khmelnytskyi and Chernivtsi regions. It should be noted that this support was achieved through the votes of the electorate of small towns and rural areas.

Parliamentary party "Opposition Platform - For Life!" did not receive the required number of votes in the region to enter the parliament (total $-4.49 \%$ ). In Lviv, Ivano-Frankivsk and Ternopil regions, this party was supported by less than $2 \%$ of voters, which corresponds to the views of the local electorate. This political structure had relative support in the polyethnic areas of the region (Zakarpattia and Chernivtsi), where more than $8 \%$ of voters supported them. This shows that the ideology suggested by this party is neither close nor understandable to the local population.

The last criterion we want to analyse is the distribution of votes between parties that represent generally antagonistic views, that is between centre-right ("European Solidarity", "Fatherland") and centrist parties ("Servant of the People", "Opposition Platform - For Life!") of a parliamentary nature. The views of the centre-right (close to the national-patriotic) direction are traditional for the regions of Western Ukraine, but in 2019, they had somewhat reduced support. On average, about $21 \%$ of voters in the region voted for parliamentary parties in this area (in Ukraine, on average, 18\%). The largest number of votes for these parties was given in the areas of their traditional support, including Lviv, Ternopil, Ivano-Frankivsk regions. Thus, in the city of Ivano-Frankivsk, Lviv and surrounding administrative districts they were supported by more than $31 \%$ of the electorate, in the central-western administrative districts of Ternopil region (Berezhany, Zboriv, Kozova, Pidhaitsi, Ternopil districts) - more than 27\%. In three regions of the research area, support for these parties was lower than the average in Ukraine - traditionally, in the polyethnic regions of Zakarpattia, Chernivtsi, and Khmelnytskyi. The minimal support of the centre-right parties was within the most polyethnic districts of the Zakarpattia region - Vynohradiv, Berehiv, Irshava, Khust districts (within 12\%).

The liberal views of the "Servant of the People" and the "Opposition Platform - For Life!" parties are generally not typical of the Western Ukrainian region. However, the views of the "Opposition Platform - For Life!" in terms of foreign policy, are often synchronous with Putin's ideas and are significantly veiled at the national level. But the 2019 election campaign went beyond the 
traditional rules. Evaluating these parties as ideologically close, it can be stated that this direction had undisputed leadership in Ukraine, however, it was ambiguously supported within the research area. On average, these parties in Ukraine were supported by more than $56 \%$ of the electorate. Only two regions in the Western Ukrainian region met this indicator, namely Zakarpattia and Chernivtsi regions. At the same time, there are administrative districts the electorate of which supported these parliamentary parties by more than $60 \%$. These districts include Hertsa, Hlyboka, Novoselytsia, Zastavna, Kelmentski, Sokyriany, Khotyn and the city of Novodnistrovsk (Chernivtsi region), Berehovo, Irshava, Mukachevo, Rakhiv, Tiachiv districts (Zakarpattia region).

At the same time, there are regions where the support for these parties is less than $20 \%$. These are regions located within the Galician ethnic territories (Lviv, Ternopil, Ivano-Frankivsk regions). The lowest support was within Lviv region (less than 24\%) and in particular within the city of Lviv (less than 19\%). This is due to the presence of the most loyal electorate, which traditionally supports national patriotic parties, and even such support for liberal ideas is rather the exception. Ivano-Frankivsk and Ternopil regions traditionally support the same views, but in the 2019 elections, parties representing this kind of ideology had a fairly high level of support (43-29\%). The results within even one area fluctuate significantly, which indicates unformed views on this ideology. A good example is Ivano-Frankivsk region. In the southern administrative territories of the region (Verkhovyna, Kosiv, Sniatyn districts), almost 43\% of the electorate supported these parties, while in the city of Ivano-Frankivsk - less than $29 \%$. This can be explained by the fact that the southern districts of this region have the highest unemployment level as well as grey sector activity and a significant number of employable people who have been working abroad for many years and now have a slightly different outlook and vision of the country's political situation. At the same time, the regional centre traditionally accumulates the most educated and patriotic electorate, that do not share these views.

\section{CONCLUSIONS}

Voter turnout in 2019 was the lowest in the history of elections in Ukraine (49.8\%) and even the Western Ukrainian region for the first time demonstrated a lower turnout than Ukraine in general. Although within this territory there are regions where the maximum indicators of participation in the elections were recorded. They are Ivano-Frankivsk $-54.2 \%$ and Lviv regions $-53.4 \%$. Traditionally, the lowest turnout was in polyethnic regions (Chernivtsi and Zakarpattia regions). Such tendencies are justified by certain sentiments of the population of the region 
in the changes, as well as social and economic reasons, for example, the holiday season and significant employment of the population of Western Ukraine in seasonal work abroad were a significant obstacle to participation in the elections.

The 2019 election campaign will go down in history of electoral geography of Ukraine as the campaign with the largest support for one political party - "Servant of the People" (43.16\%). On average in the Western Ukrainian region, this figure was slightly lower (39.76\%). At the same time, there are regions with significantly lower indicators (Lviv region $-22.19 \%$; this was the lowest support indicator for the leader of the parliamentary race in Ukraine), as well as those where this indicator was significantly exceeded (Chernivtsi region $-50.68 \%$, Zakarpattia region $-50.44 \%$ ). This is a sign of intra-regional ideological differences and the level of political formation of the regional electorate.

Entering of "new" parliamentary parties to the Ukrainian parliament is a sign of another attempt to find political groups that should radically change the situation in the country. Their confrontation with the old parliamentary forces is a kind of motivator for the latter in the struggle for the spheres of influence as well as the electorate. The rationality of the voters' thinking in a particular region can be assessed by the number of votes cast for the passing "parliamentary" parties. More than $74 \%$ of voters in the Western Ukrainian region supported those parties that joined the parliament (this figure is quite different from the national one). Five regions (Zakarpattia, Ivano-Frankivsk, Lviv, Rivne, Chernivtsi) provided higher support for the parties that entered the parliament when compared with other regions, meaning the regional average.

The $50 \%$ support for new parliamentary parties is a clear confirmation of hopes for change, which they embodied. Only a quarter of voters in particular regions stand out in this election campaign with the established views they have always possessed. This is an unconventional indicator for the region and shows that part of the electorate is in search of their political preferences.

A very clear criterion of political differences in the Western Ukrainian region is the confrontation in support for centre-right ("European Solidarity", "Fatherland") and centrist parties with liberal views ("Servant of the People", "Opposition Platform - For Life!"). On average, about 21\% of voters in the region supported the centre-right parliamentary parties, which is higher than the average in Ukraine (18\%) and corresponds to the traditions of the Western Ukrainian region. Liberal parties are not typical for the research region, but in 2019, they had support, which ranged from 19\% in some regional centres (Lviv) to $60 \%$ in the administrative districts of Chernivtsi and Zakarpattia regions. It can be stated that this direction had undisputed leadership in Ukraine, but it was ambiguously supported within the research area. 


\section{REFERENCES}

\section{Literature}

Ansolabehere S., Konisky D.M. 2006. The Introduction of Voter Registration and Its Effect on Turnout. Political Analysis 14, 83-100. https://doi.org/10.1093/pan/mpi034

Bakumov O.S. 2015. Electoral Behavior of Ukrainian Voters in 2010-2014: Cluster Analysis. Forum prava 3, 19-24.

Brajchevskyj Yu.S. 2013. The Concept of Place as a Factor of Electoral Behavior and Regional Political Polarization in Ukraine. Economic and Social Geography 2(67), 67-74.

Cherkashyn K.V. 2005. Elektoralna povedinka naselennia nezalezhnoi Ukrainy $v$ rehionalnykh zrizakh. Avtoref. dys... kand. polit. nauk: 23.00.02 Tavr. nats. un-t im. V.I.Vernadskoho. Simferopol.

Dettrey B.J., Schwindt-Bayer L.A. 2009. Voter Turnout in Presidential Democracies. Comparative Political Studies 42(10), 1317-1338. https://doi.org/10.1177/0010414009332125

Haydukiewicz L. 2011. Electoral Geography as a New Mean of Analyzing Social Change Krakow City and Malopolskie Voivodship Case Study. Bulletin of Geography. Socio-Economic. Series 15, 95-115. https://doi.org/10.2478/v10089-011-0007-8

Hogan R.E. 2013. Campaign Spending and Voter Participation in State Legislative Elections. Social Science Quarterly 94, 840-864. https://doi.org/10.1177/1532673X99027004002

Holbrook T.M., Weinschenk A.C. 2014. Campaigns, Mobilization, and Turnout in Mayoral Elections. Political Research Quarterly 67(1), 42-55. https://doi.org/10.1177/1065912913494018

Eggers A.C. 2015. Proportionality and Turnout: Evidence From French Municipalities. Comparative Political Studies 48(2), 135-167. https://doi.org/10.1177/0010414014534199

Endersby J.W., Krieckhaus, J.T. 2008. Turnout around the Globe: The Influence of Electoral Institutions on National Voter Participation, 1972-2000. Electoral Studies 27, 601-610. https://doi. org/10.1016/j.electstud.2008.05.004

Fowler A. 2013. Electoral and Policy Consequences of Voter Turnout: Evidence from Compulsory Voting in Australia. Quarterly Journal of Political Science 8, 159-182. https://doi. org/10.2139/ssrn.1816649

Fauvelle-Aymar C., François A. 2006. The Impact of Closeness on Turnout: An Empirical Relation Based on a Study of a Two-Round Ballot. Public Choice 127, 469-491. https://doi. org/10.1007/s11127-005-9004-x

Kolodij A. 2006. Ukrainian Regionalism as a State of Cultural and Political Polarization. In: A. Kolodij (ed.), AGORA. Issue 3: Ukraine - Regional Dimension (pp. 69-91). Kyiv: Stylus.

Kuzyshyn A.V. 2017. Displays of Electoral Culture in the Electoral Field of the Carpathian-Podolsk Region. Odesa National University Herald. Geography and Geology 30(1), 162-172.

Kuzyshyn A.V. 2019. Social-Geographical Analysis of the Electoral Field of the Western Ukrainian Region. The Scientific Issues of Ternopil Volodymyr Hnatiuk National Pedagogical University. Series: Geography 47(2), 59-66.

Kuzyshyn A.V. 2020. Spatial Analysis of Electoral Sympathies of the Population of the Western Ukraine Region According to the Results of the Elections to the Verhovna Rada of 2019. Odesa National University Herald. Geography and Geology 30(1), 153-172.

Kowalski M. 2003. Polaryzacja zachowań wyborczych w Polsce jako rezultat cywilizacyjnego rozdarcia kraju. In: M. Kowalski (red.), Przestrzeń wyborcza Polski (pp. 11-48). Warszawa: PTG, PAN IGiPZ.

Kowalski M. 2004. Regionalne zróżnicowanie zachowań wyborczych Polaków w latach 19892001. In: T. Markowski (red.), Przestrzeń w zarzadzaniu rozwojem regionalnym i lokalnym (pp. 407-430). Warszawa: KPZK PAN. 
Krzemiński P. 2009. Zachowania wyborcze w wyborach parlamentarnych i prezydenckich w Polsce w latach 2005-2007 - wzory przestrzennych zróżnicowań. Przegląd Geograficzny 81(2), 259-281. https://doi.org/10.7163/PrzG.2009.2.5

Lasoń A., Torój A. 2019. Anti-Liberal, Anti-Establishment or Constituency-Driven? Spatial Econometric Analysis of Polish Parliamentary Election Results in 2015. European Spatial Research Policy 26(2), 199-236. https://doi.org/10.18778/1231-1952.26.2.10

Mansley E., Demsar U. 2015. Space Matters: Geographic Variability of Electoral Turnout Determinants in the 2012 London Mayoral Election. Electoral Studies 40, 322-334. https://doi. org/10.1016/j.electstud.2015.10.003

Nikolenyi C. 2010. Concurrent Elections and Voter Turnout: The Effect of the De-Linking of State Elections on Electoral Participation in India's Parliamentary Polls, 1971-2004. Political Studies 58(1), 214-233. https://doi.org/10.1111/j.1467-9248.2009.00779.x

Vyshnyak O. 2008. Political Typology of Regions of Ukraine: Dynamics and Factors of Change. In: F. Rudych (ed.), Ukrainian Society 1992-2008. Sociological Monitoring (pp. 331-342). Kyiv: Institute of Sociology. NAS of Ukraine.

Zarycki T. 1997. Nowa przestrzeń społeczno-polityczna Polski. Seria: Studia regionalne i lokalne, 23(56). Warszawa: UW, EIRRiL, p. 237.

Zarycki T. 2002. Region jako kontekst zachowań politycznych. Warszawa: Scholar.

\section{Netography}

Abstention and Voting Behaviour in the 2009 European Elections. Online: https://www.europarl. europa.eu/at-your-service/en/be-heard/eurobarometer/abstention-and-voting-behaviour-inthe-2009-european-elections (access: 20.05.2021).

BBC News. Ukraine. Online: www.bbc.com/ukrainian/features-49133636 (access: 20.05.2021).

Ilko Kucheriv Democratic Initiatives Foundation. 2019. Online: www.dif.org.ua/article/khto-za-kogo-progolosuvav-demografiya-natsionalnogo-ekzit-polu-na-parlamentskikh-viborakh-2019?fbclid=IwAR1Dwb0ZtNljHrF2Wgo9BRN0PCPSD09M8sFc916GQDBIOMuns3Ze-W0pRw (access: 20.05.2021).

Saib M. 2017. Spatial Autocorrelation in Voting Turnout. Journal of Biometrics \& Biostatistics 8(5). Online: https://www.hilarispublisher.com/open-access/spatial-autocorrelation-in-voting-turnout-2155-6180-1000376.pdf

The Central Election Commission of Ukraine. Online: www.cvk.gov.ua/ (access: 20.05.2021). 